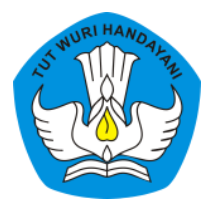

Page: 803-818

\title{
Media Puzzle Edukasi untuk Meningkatkan Aktivitas dan Hasil Belajar Siswa
}

\author{
Rona Norhana Dewi \\ Sekolah Menengah Pertama Negeri 6 Tanjung, Tabalong, Kalimantan Selatan \\ Contributor Email: nurhana_rnd@yahoo.co.id
}

Article Url: http://ojsdikdas.kemdikbud.go.id/index.php/didaktika/article/view/113

\begin{abstract}
The research objective is to improve the learning activity and competency through "Puzzle Edukasi" of the seventh-grade students in SMPN 6 Tanjung in the Academic Year 2018/2019. The learning material consisted of Norm and Justice. The year 2018/2019. The design used classroom action research implemented in two cycles. Every cycle has four phases, they are planning, implementing, action, observation, and reflection. The research subjects recruited 12 male and 12 female students. Observation, tests, and questionnaires are used as instruments for data collection. Based on the finding and discussion, it can be concluded that students' activity and competency of VII A of SMPN 6 Tanjung were improved through "Puzzle Edukasi" media. It is shown by the average score of the students' activity, which was improved from the first cycle to the second cycle. On other hand, students' response toward learning is dominant. Students agreed that learning PPKn with Puzzle Edukasi media can improve learning activity and competency as well as much as $96.88 \%$.
\end{abstract}

Keywords: Puzzle Edukasi, Activity, Competency 


\begin{abstract}
Abstrak
Tujuan penelitian ini adalah untuk meningkatkan aktivitas dan hasil belajar siswa menggunakan media Puzzle Edukasi pada materi Norma dan Keadilan. Penelitian ini merupakan Penelitian Tindakan Kelas yang dilaksanakan secara berdaur dengan 2 siklus. Setiap siklus terdiri dari empat tahapan, yaitu perencanaan, pelaksanaan tindakan, pengamatan, dan refleksi. Subjek penelitian adalah siswa kelas VII A dengan jumlah siswa 24 orang, terdiri dari 12 orang laki-laki dan 12 orang perempuan. Metode pengumpulan data: observasi, tesdan angket. Berdasarkan analisis data disimpulkan bahwa aktivitas dan hasil belajar siswa kelas VII A SMP Negeri 6 Tanjung pada materi Norma dan Keadilan dapat ditingkatkan melalui penggunaan media pembelajaran Puzzle Edukasi. Hal tersebut terlihat dari skor rata-rata aktivitas siswa yang relevan dengan pembelajaran mengalami peningkatan dari siklus pertama sampai siklus kedua. Sementara untuk respon siswa terhadap pembelajaran adalah dominan siswa setuju bahwa pembelajaran PPKn dengan media pembelajaran Puzzle Edukasi dapat meningkatkan aktivitas dan hasil belajar siswa dengan persentase 96,88\%.
\end{abstract}

Kata Kunci: Media Puzzle; Edukasi; Hasil Belajar; Siswa

\title{
A. Pendahuluan
}

Proses belajar mengajar adalah suatu kegiatan interaksi yang dinamis antara pendidik yang melaksanakan tugas mengajar dengan peserta didik yang melaksanakan kegiatan belajar dalam rangka mencapai tujuan yang telah ditetapkan. Pendidikan berfungsi membantu siswa dalam pengembangan dirinya, yaitu pengembangan semua potensi, kecakapan, serta karakteristik pribadinya ke arah yang lebih positif, baik bagi dirinya maupun lingkungannya.

Selain itu, guru juga harus mampu membekali siswa dengan berbagai kompetensi seperti pengetahuan, sikap atau karakter yang kuat, serta ketrampilan yang memadai untuk menghadapi tantangan abad ke21. Ketrampilan yang dibutuhkan siswa antara lain kemampuan berpikir kritis, kreatif, berkomunikasi yang baik, berkolaborasi, dan berkarakter kuat.

Hal lain yang dapat dilakukan oleh guru dalam menciptakan proses pembelajaran yang kaya dan bermakna, di antaranya yaitu 
menggunakan media pembelajaran yang tepat (Yunus, 2015). Dalam hal ini, guru tentunya bukan hanya sekedar menggunakan media pembelajaran yang dapat memahamkan siswa pada materi pelajaran, tetapi media pembelajaran yang mampu menggali serta mengasah potensi dan ketrampilan siswa. Media pembelajaran yang digunakan guru hendaknya dapat menginspirasi sekaligus memfasilitasi siswa sehingga aktif dalam proses pembelajaran.

SMP Negeri 6 Tanjung pada Tahun Pelajaran 2018/2019 sudah melaksanakan Kurikulum 2013 pada semua tingkatan. Sebagai sekolah yang sudah melaksanakan kurikulum 2013, proses pembelajaran yang berlangsung pada umumnya sudah bervariasi, baik dalam penggunaan strategi, metode, maupun media pembelajaran. Hal tersebut terlihat pada Rencana Pelaksanaan Pembelajaran (RPP) yang digunakan oleh guru dalam mengajar. Akan tetapi penggunaan strategi, metode, dan media yang digunakan oleh guru dalam proses pembelajaran adalah metode diskusi dan persentasi biasa sehingga terkesan proses pembelajaran masih didominasi oleh guru.

Pendidikan Pancasila dan Kewarganegaraan merupakan mata pelajaran yang memfokuskan agar peserta didik memiliki sikap kewarganegaraan yang baik, memiliki rasa kebanggaan terhadap Negara Indonesia, cinta tanah air, jujur, disiplin, tanggung jawab, santun, peduli, dan percaya diri dalam berinteraksi di lingkungan rumah, sekolah, dan sekitarnya serta berbangsa dan bernegara (Kemendikbud, 2016)

Berdasarkan pengamatan pada siswa di SMPN 6 Tanjung, khususnya kelas VIIA, mata pelajaran PPKn dianggap pelajaran yang hanya mementingkan hafalan dan membosankan, sehingga menyebabkan rendahnya aktivitas dan hasil belajar PPKn. Selain itu ditunjang pula dengan permasalahan yang sering dialami adalah pemadaman listrik secara bergiliran oleh PLN dalam jangka waktu yang lama dan sarana telekomunikasi seperti handphone yang sering mengalami gangguan signal, serta lemahnya akses internet mengakibatkan guru sering 
mengalami hambatan dalam menggunakan media dan sumber belajar yang berhubungan dengan elektronik. Dari hasil belajar siswa pada materi Perumusan dan Penetapan Pancasila sebagai Dasar Negara diperoleh data sebagai berikut rata-rata kelas 65, dari 24 siswa ada 10 siswa $(41,66 \%)$ sudah mencapai KKM 71 sedangkan 14 lainnya (58,33\%) belum mencapai karena nilainya masih di bawah KKM.

Dari data tersebut, aktivitas dan hasil belajar siswa pada materi Perumusan dan penetapan Pancasila Sebagai Dasar negara masih jauh dari hasil yang diharapkan. Mengatasi permasalahan tersebut, penulis termotivasi untuk memperbaiki dan menciptakan proses pembelajaran yang kaya dan bermakna. Hal tersebut dilakukan untuk memunculkan kompetensi siswa yang dibutuhkan pada abad ke-21, yaitu dengan cara menggunakan media pembelajaran. Media pembelajaran yang digunakan adalah Puzzle Edukasi. Media ini digunakan untuk meningkatkan aktivitas dan hasil belajar siswa serta tepat digunakan dalam penguatan pendidikan karakter. Hal ini karena aktivitas dalam proses pembelajaran dengan menggunakan media tersebut dapat membentuk karakter yang kuat kepada siswa. Penggunaan media pembelajaran yang dibuat oleh penulis sesuai dengan salah satu prinsip dari pengembangan dan implementasi penguatan pendidikan karakter berbasis kelas menurut (Kemendikbud, 2016) yaitu sarana atau media yang digunakan sebaiknya mengembangkan kecakapan-kecakapan yang dibutuhkan siswa untuk hidup pada abad 21. Pembelajaran tersebut dapat digunakan untuk masa depan serta merupakan salah satu cara yang dapat dipakai dalam pembelajaran abad 21 serta memiliki potensi untuk meningkatkan aktivitas dan hasil belajar siswa.

Melalui media pembelajaran yang digunakan oleh guru, siswa akan terlibat dalam aktivitas pembelajaran yang membahagiakan sekaligus dapat mengoptimalkan kompetensi, pengetahuan, selalu berfikir kritis, dan kreatif karena terbiasa berlatih, berkomunikasi, dan berkolaborasi dengan baik, hasil belajar yang baik, sekaligus mempunyai karakter yang kuat. 
Melihat latar belakang tersebut, penulis pada materi Norma dan Keadilan tertarik menggunakan media Puzzle Edukasi, karena dianggap dapat meminimalisir kendala yang pernah penulis temukan, tidak memerlukan biaya yang besar karena menggunakan barang bekas yang ada di sekitar lingkungan, tidak memerlukan waktu yang lama dalam pembuatan, tidak perlu menggunakan sumber listrik, tidak memerlukan infokus serta peralatan elektronik lainnya untuk menampilkannya di depan kelas tetapi menunjang dalam pembelajaran abad ke-21.

\section{B. Metode}

Siswa kurang kreatif, terkesan pasif dan tidak memiliki motivasi untuk mengikuti pelajaran, pertanyaan jarang muncul ketika proses pembelajaran berlangsung, tidak ada kerjasama antar siswa dalam kelompok serta sulitnya siswa dalam memahami materi Norma dan keadilan. Selain pada siswa, guru juga belum secara penuh memberikan kegiatan yang mampu mengaktifkan siswa, seperti menggunakan media, metode atau model pembelajaran yang tepat. Hal inilah yang terjadi pada proses belajar mengajar PPKn di kelas VII A pada SMPN 6 Tanjung yang menyebabkan hasil belajar belum mencapai ketuntasan secara maksimal.

Untuk mengatasi permasalahan tersebut, penelitian tindakan kelas dengan Puzzle Edukasi digunakan dalam proses pembelajaran pada siswa SMPN 6 Tanjung khususnya siswa kelas VII A, karena dengan media Puzzle Edukasi ini, kendala yang pernah dialami penulis pada saat melaksanakan pembelajaran dan diskusi kelompok dapat diminimalisir. Selain itu media ini juga tidak memerlukan biaya yang besar, tidak memerlukan waktu yang lama dalam pembuatan, tidak perlu menggunakan sumber listrik dan tidak memerlukan infokus serta peralatan listrik lainnya untuk menampilkannya di depan kelas.

Diharapkan melalui penerapan media ini siswa akan menjadi lebih aktif dalam kegiatan pembelajaran, pemahaman siswa terhadap konsep yang diajarkan akan meningkat dan siswa lebih mudah dalam memaknai 
serta menelaah tentang Norma dan Keadilan dalam berbagai kehidupan, sehingga hasil belajar siswa dapat mencapai kriteria ketuntasan yang ditentukan.

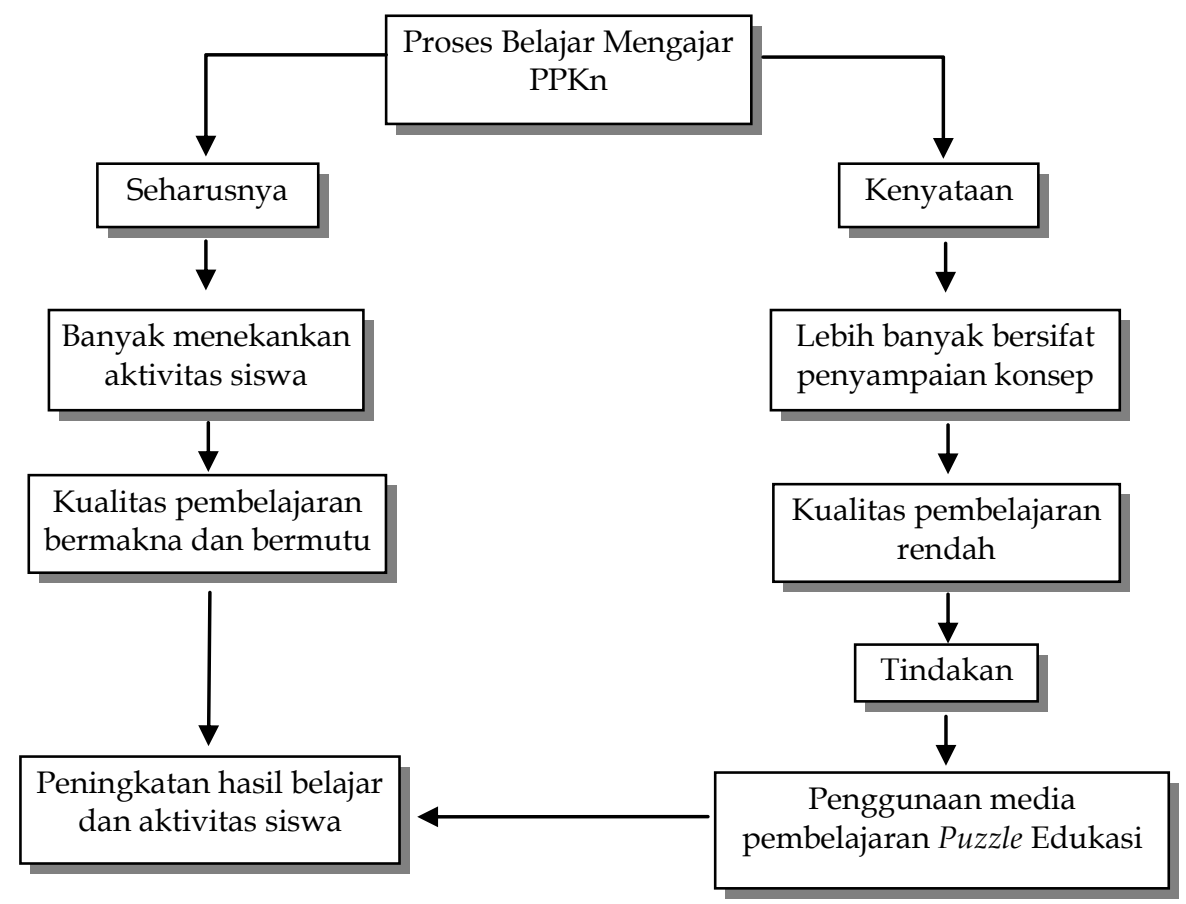

Gambar 1 Rancangan Desain Penelitian

Subjek dalam penelitian ini adalah siswa kelas VIIA SMPN 6 Tanjung Tahun Pelajaran 2018/2018 yang berjumlah 24 orang, yang terdiri dari 12 orang siswa laki-laki dan 12 orang siswa perempuan. Penelitian dilaksanakan di SMPN 6 Tanjung yang terletak di Desa Kambitin Raya, Kecamatan Tanjung, Kabupaten Tabalong. Penelitian dilaksanakan pada saat mata pelajaran Pendidikan Pancasila dan Kewarganegaraan (PPKn) dengan materi "Norma dan Keadilan".

Instrumen penelitian terkait aktivitas belajar siswa dan aktivitas guru disusun berdasarkan identifikasi masalah melalui lembar pengamatan. Instrumen untuk hasil belajar disusun berdasarkan materi di akhir kegiatan pada setiap siklus. Instrumen penelitian untuk aktivitas 
siswa dan aktivitas guru diobservasi oleh 1orang guru yang sudah ditunjuk yaitu Bapak Suhaimi, S.Sos untuk mengamati aktivitas siswa dan aktivitas guru.

Untuk mengumpulkan data dalam penelitian tindakan kelas ini digunakan beberapa metode pengumpulan data. Metode pengumpulan data yang digunakan sebagai berikut.

1. Observasi, teknik ini digunakan untuk memperoleh data tentang aktivitas siswa dan aktivitas guru dalam proses pembelajaran.

2. Tes, teknik ini digunakan untuk memperoleh data hasil belajar siswa yang dicapai selama proses pembelajaran dengan menggunakan media pembelajaran Puzzle Edukasi yang dilakukan diakhir siklus.

3. Angket, teknik ini digunakan untuk memperoleh data mengenai respon siswa terhadap proses pembelajaran dengan menggunakan media pembelajaran Puzzle Edukasi.

Penelitian Tindakan Kelas ini terdiri dari 2 siklus. Siklus pertama terdiri dari 2 kali pertemuan dan siklus kedua terdiri dari 2 kali pertemuan. Dalam hal ini setiap pertemuan dengan durasi waktu $3 \times 40$ menit. Teknik analisis data yang digunakan dalam penelitian ini adalah statistik deskriptif yang berupa persentase.

Persentase digunakan untuk mengetahui aktivitas siswa dan keterlaksanaan langkah-langkah selama pelaksanaan KBM yang berdasarkan media pembelajaran Puzzle Edukasi yaitu menggunakan teknik analisis persentase yang dihitung dengan rumus:

$$
P=\frac{\text { skor yang diperoleh }}{\text { skor maksimum }} \times 100 \%
$$

Keterangan:

$P=$ Angka persentase 
Tabel 1. Kriteria Aktivitas Belajar Siswa

\begin{tabular}{|l|l|}
\hline \multicolumn{1}{|c|}{ Interval (\%) } & \multicolumn{1}{|c|}{ Kriteria } \\
\hline Aktivitas siswa $<25 \%$ & Tidak Aktif \\
\hline $26 \%-45 \%$ & Kurang Aktif \\
\hline $46 \%-65 \%$ & Cukup Aktif \\
\hline $66 \%-85 \%$ & Aktif \\
\hline $86 \%-100 \%$ & Sangat Aktif \\
\hline
\end{tabular}

Sumber: Riduwan (Saudah, 2013)

Persentase aktivitas guru dianalisis dengan perhitungan menurut rumus sebagai berikut.

Nilai $=\sum N \sum$ Aspek $x$ Maks.penilaian $\quad 00 \%$

Keterangan:

$N=$ Nilai

Tabel 2. Kualifikasi Aktivitas Guru

\begin{tabular}{|c|c|}
\hline Interval (\%) & Kriteria \\
\hline $85 \%-100 \%$ & Sangat baik \\
\hline $70 \%-84 \%$ & Baik \\
\hline $55 \%-69 \%$ & Cukup Baik \\
\hline $40 \%-54 \%$ & Kurang \\
\hline $0 \%-25 \%$ & Sangat Kurang \\
\hline
\end{tabular}

Sumber: Oemar Hamalik (Saudah, 2013)

Pada perhitungan persentase siswa yang telah atau belum mencapai KKM berdasarkan hasil belajar mereka digunakan rumus persentase dari Sudijono (2011) dengan rumus:

$$
P=\frac{\text { jumlah siswa yang belajar tuntas }}{\text { jumlah seluruh siswa }} \times 100 \%
$$

Keterangan:

$P=$ persentase ketuntasan belajar

$f=$ jumlah siswa belajar yang belajar tuntas

$N=$ jumlah seluruh siswa

Perhitungan rata-rata hasil belajar siswa menggunakan rumus berikut.

$$
\mathbb{M}_{\mathbb{R}}=\frac{\sum x}{\mathbb{P}}
$$


Keterangan:

$\mathrm{M}_{x}=$ rata-tata (mean)

$\sum x=$ jumlah seluruh skor

$N$ = banyaknya Objek (Sudijono:2011)

Angka persen yang diperoleh menunjukan daya serap siswa atau tingkat keberhasilan yang dicapai siswa setelah pelaksanaan pembelajaran. Nilai rata-rata yang diperoleh termasuk kualifikasi istimewa, amat baik, baik, cukup, atau amat kurang.

Tabel 3. Kualifikasi Tingkat Keberhasilan Siswa

\begin{tabular}{|l|l|}
\hline Nilai rata-rata siswa & Kualifikasi \\
\hline $\mathbf{2} 95,0$ & Istimewa \\
\hline $80,0-94,9$ & Amat baik \\
\hline $65,0-79,9$ & Baik \\
\hline $55,0-64,9$ & Cukup \\
\hline $40,1-54,9$ & Kurang \\
\hline $\mathbf{S} 40,0$ & Amat kurang \\
\hline
\end{tabular}

Respon siswa dianalisis menggunakan teknik persentase (\%) dengan rumus:

$$
\text { Persentase respon siswa }=\frac{\text { Jumlah jawaban YA siswa }}{\text { Jumlah seluruh } \text { siwa }} \times 100 \%
$$

Respon siswa dikategorikan positif apabila persentase yang diperoleh lebih dari 80\% (Widjonarko, 2011)

\section{Hasil dan Pembahasan}

Berdasarkan hasil refleksi terkait perkembangan aktivitas belajar dicapai siswa dari siklus I ke siklus ke II dapat dilihat pada tabel berikut ini:

Tabel 4. Hasil Observasi Aktivitas Siswa Siklus I dan II

\begin{tabular}{cccccc}
\hline \multirow{2}{*}{ No } & \multicolumn{2}{c}{ Aspek yang diamati } & \multicolumn{2}{c}{ Siklus } & \multirow{2}{*}{ Reningkatan } \\
& & & $\%$ & Rata-rata II & Peningata \\
1 & Siswa & secara pro aktif menjawab & 62,50 & 72,68 & $\%$ \\
\hline
\end{tabular}




\begin{tabular}{|c|c|c|c|c|}
\hline & pertanyaan dari guru & & & \\
\hline 2 & $\begin{array}{l}\text { Siswa memiliki keberanian dalam } \\
\text { mengemukakan pendapat }\end{array}$ & 64,89 & 74,52 & 7,79 \\
\hline 3 & $\begin{array}{l}\text { Siswa memiliki motivasi dalam } \\
\text { mengikuti pembelajaran }\end{array}$ & 66,67 & 72,62 & 7,85 \\
\hline 4 & $\begin{array}{l}\text { Siswa pro aktif dalam menyelesaikan } \\
\text { LKK yang sudah ditugaskan }\end{array}$ & 63,10 & 72,08 & 8,99 \\
\hline 5 & $\begin{array}{l}\text { Siswa mau dan mampu berdiskusi } \\
\text { dengan kelompoknya }\end{array}$ & 64,89 & 72,68 & 7,79 \\
\hline 6 & $\begin{array}{l}\text { Siswa menyelesaikan tugas sesuai } \\
\text { dengan waktu yang telah ditentukan }\end{array}$ & 67,86 & 75,71 & 7,85 \\
\hline \multirow[t]{2}{*}{7} & $\begin{array}{l}\text { Siswa berani mempersentasikan hasil } \\
\text { kerja kelompoknya. }\end{array}$ & 63,10 & 71,43 & 8,33 \\
\hline & Rata-rata & 64,71 & 73,11 & 8,40 \\
\hline
\end{tabular}

Berdasarkan tabel 4 tentang perkembangan aktivitas belajar siswa di atas, menunjukkan terjadi peningkatan aktivitas belajar siswa. Dalam hal ini rata-rata peningkatan aktivitas belajar siswa dalam setiap aspek sebesar 8,40\% dan semua aspek aktivitas mencapai kriteria aktif. Ini berarti indikator keberhasilan dalam penelitian ini sudah tercapai. Untuk lebih memperjelas peningkatan perkembangan aktivitas belajar siswa, dapat dilihat pada grafik berikut:

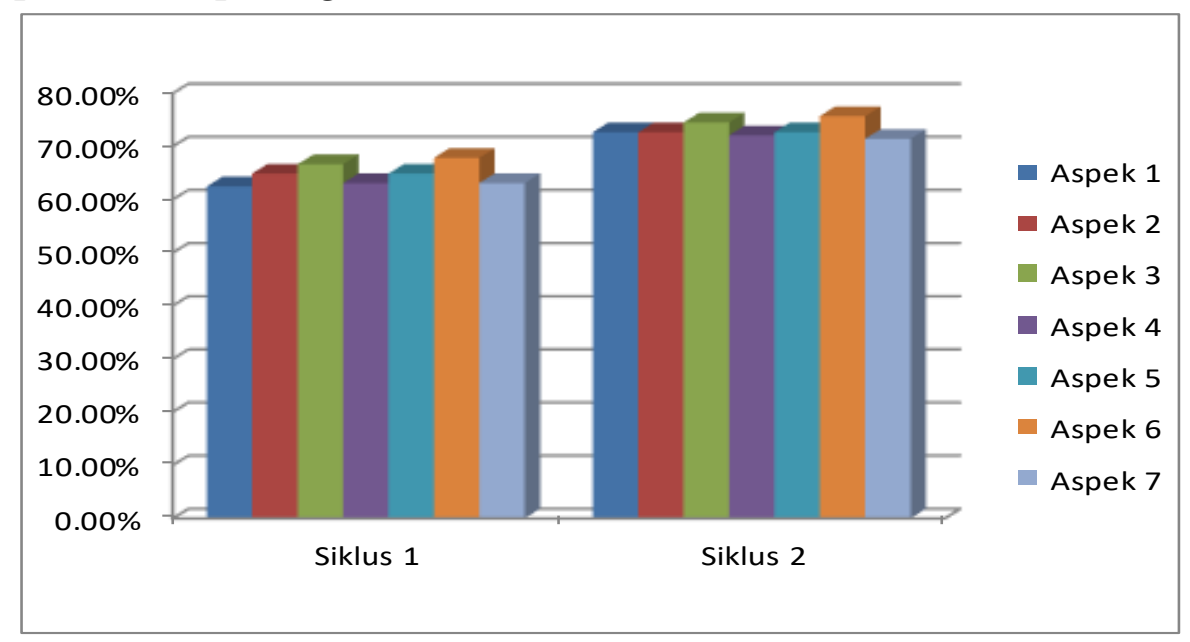

Grafik 1 Perkembangan Aktivitas Belajar Siswa Siklus I dan II

Hasil observasi terkait dengan aktivitas guru dari siklus I ke siklus II dapat dilihat pada tabel 5 berikut ini: 
Tabel 5: Hasil Observasi Aktivitas Guru Siklus I dan II

\begin{tabular}{cccccccc}
\hline & \multicolumn{4}{c}{ Siklus I } & \multicolumn{3}{c}{ Siklus II } \\
Aktivitas & Pert. 1 & Pert. 2 & Rata-Rata & Pert. 1 & Pert. 2 & Rata-Rata & Peningkatan \\
per siklus \\
guru & $\%$ & $\%$ & $\%$ & $\%$ & $\%$ & $\%$ & $\%$ \\
& 63,15 & 73,68 & 68,42 & 78,94 & 84,21 & 81,58 & 13,16 \\
\hline
\end{tabular}

Untuk lebih memperjelas peningkatan perkembangan aktivitas guru, dapat dilihat pada grafik 2 berikut:

Grafik 2: Perkembangan aktivitas guru Siklus I (Pertemuan 1 dan 2) dan Siklus II (Pertemuan 3 dan 4)

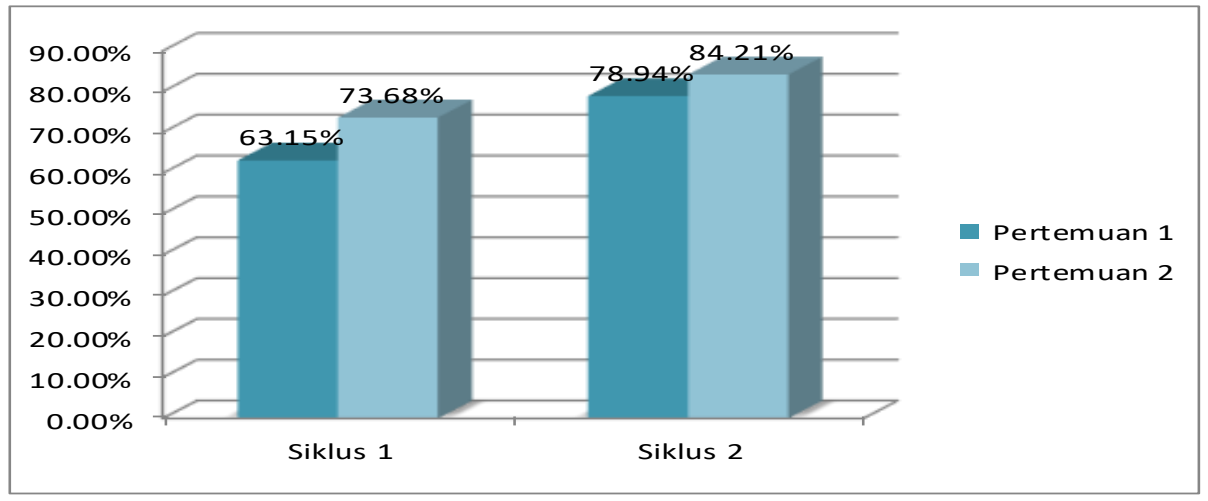

Grafik 2 Perkembangan Aktivitas Guru Siklus I (Pertemuan 1 dan 2) dan Siklus II (Pertemuan 3 dan 4)

Beberapa faktor penyebab terjadinya peningkatan aktivitas belajar siswa dalam pembelajaran dengan menggunakan media Puzzle Edukasi di antaranya sebagaiberikut.

1. Guru berupaya memberikan motivasi dan mendorong siswa untuk mengumpulkan informasi serta data untuk menyelesaikan yang sudah ditugaskan.

2. Guru berupaya meningkatkan kualitas motivasi dengan memberikan bimbingan dan arahan kepada setiap kelompok, khususnya untuk kelompok-kelompok yang mengalami masalah dalam menyelesaikan tugas.

3. Guru memberikan reward dalam berbagai bentuk baik berupa ucapan, tepuk tangan dan acungan jempol. 
Berdasarkan hasil evaluasi terkait perkembangan hasil belajar yang dicapai siswa dari siklus I ke siklus ke II dapat dilihat pada grafik 3 berikut ini:

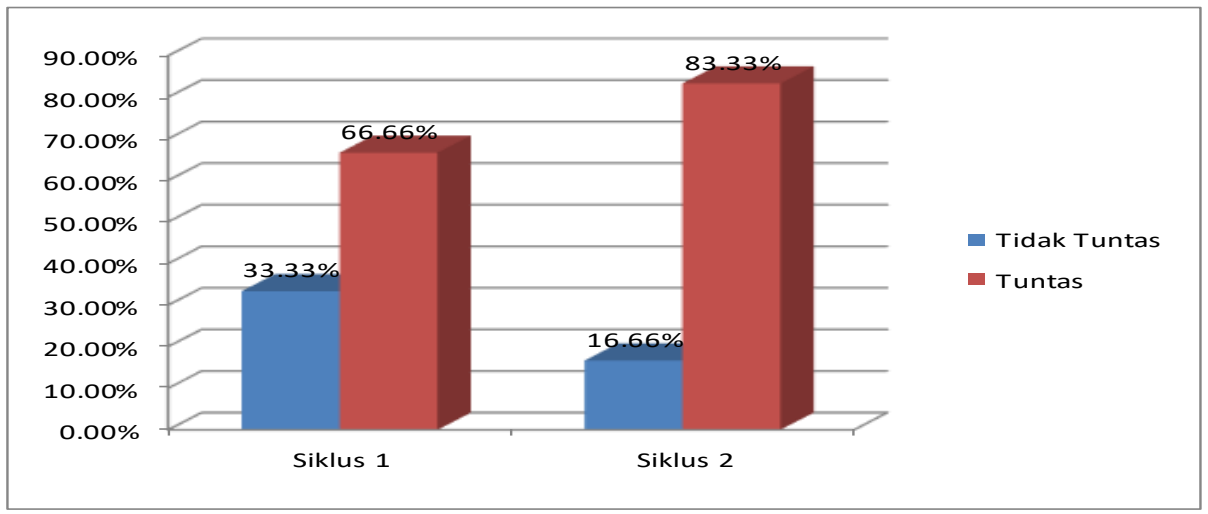

Grafik 3 Ketuntasan Hasil Belajar (Pengetahuan) Siklus I dan II

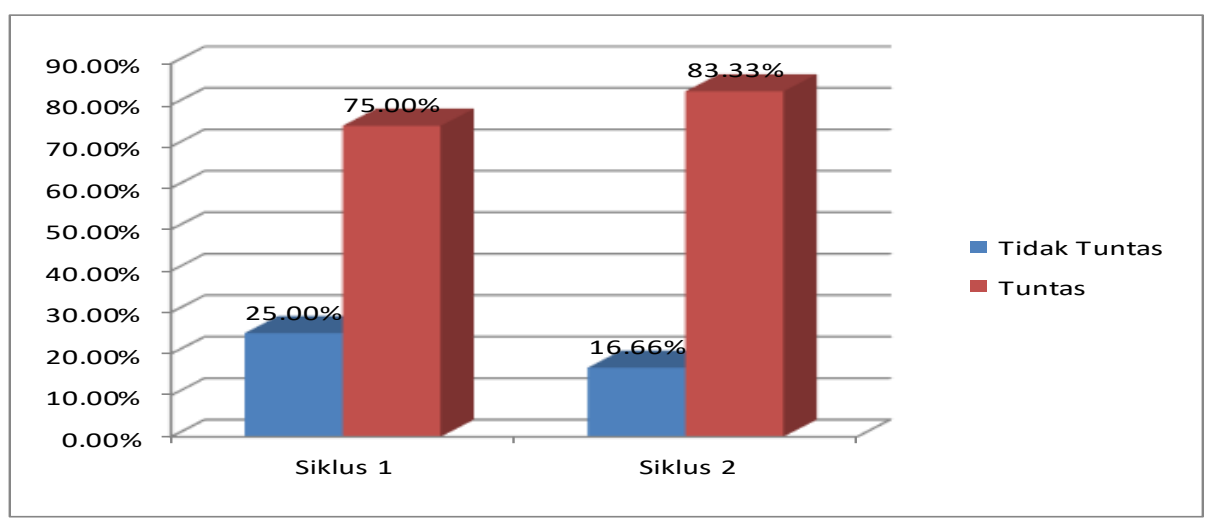

Grafik 4 Ketuntasan Hasil Belajar (Ketrampilan) Siklus I dan II

Grafik 3 tersebut menunjukkan adanya kenaikan hasil belajar (pengetahuan), hal ini terlihat pada ketuntasan yang semakin meningkat dari sebelum pelaksanaan $41,66 \%$ menjadi $66,66 \%$ pada siklus I dan 83,33\% pada siklus II. Sedangkan pada Grafik 4 nilai ketrampilan menunjukkan kenaikan pada hasil ketrampilan pada siklus I 75,00\% menjadi 83,33 \% pada siklus II. Hal ini membuktikan bahwa penggunaan media Puzzle Edukasi sangat membantu dalam meningkatkan aktivitas 
dan hasil belajar siswa. Selain itu juga membawa dampak positif yang dapat dirasakan secara langsung dalam pembelajaran, yaitu proses pembelajaran menjadi lebih bermakna, hal ini terlihat dari awal sampai akhir proses pembelajaran siswa terlibat secara aktif.

Berdasarkan hasil perkembangan hasil belajar yang dicapai siswa di atas, menunjukkan terjadi peningkatan ketuntasan hasil belajar.Ini berarti indikator keberhasilan dalam penelitian ini sudah tercapai. Beberapa faktor penyebab terjadinya peningkatan ketuntasan hasil belajar tersebut adalah sebagai berikut:

1. Dilihat dari aktivitas belajar siswa selama pembelajaran dengan media pembelajaran Puzzle Edukasi berlangsung, ada peningkatan kualitas aktivitas belajar siswa dari siklus I ke siklus II. Aktivitas belajar siswa sangat mempengaruhi pencapaian hasil belajar siswa. Hal ini dikarenakan banyak faktor yang mempengaruhi dan saling berkaitan antara satu faktor dengan faktor yang lainnya dalam pencapaian hasil belajar siswa. Salah satu faktor yang mempengaruhi adalah aktivitas belajar siswa dan aktivitas guru selama proses pembelajaran.

2. Dilihat dari perbaikan proses yaitu meningkatnya kualitas pada aktivitas kegiatan guru yakni adanya kegiatan pendahuluan melalui media appersepsi, memberikan motivasi, mendorong siswa untuk mengumpulkan informasi dan data yang sesuai tugas pada Puzzle Edukasi, memberikan bimbingan dan arahan kepada setiap kelompok, khususnya untuk kelompok-kelompok yang mengalami masalah dalam menyelesaikan tugas serta guru memberikan reward dalam berbagai bentuk.

Sementara kitu, untuk respon siswa secara keseluruhan terhadap pembelajaran dengan menggunakan media pembelajaran Puzzle Edukasi adalah dominan siswa setuju bahwa pembelajaran PPKn dengan media pembelajaran Puzzle Edukasi dapat meningkatkan aktivitas dan hasil belajar siswa. 


\section{Tabel 6: Hasil Respon Peserta Didik terhadap Pembelajaran}

\begin{tabular}{|c|c|c|c|c|}
\hline No & Uraian & Respon & Jumlah & Persentase \\
\hline \multirow[b]{2}{*}{1} & Merasa senang selama mengikuti pembelajaran & Ya & 24 & $100 \%$ \\
\hline & $\begin{array}{l}\text { yang disajikan guru dengan menggunakan media } \\
\text { pembelajaran Puzzle Edukasi }\end{array}$ & Tidak & 0 & $0 \%$ \\
\hline \multirow{2}{*}{2} & Merasa lebih termotivasi dalam mengikuti proses & Ya & 24 & $100 \%$ \\
\hline & belajar mengajar yang disajikan oleh guru & Tidak & 0 & $0 \%$ \\
\hline \multirow[b]{2}{*}{3} & Merasa senang belajar PPKn apabila materi yang & Ya & 24 & $100 \%$ \\
\hline & $\begin{array}{l}\text { disajikan dihubungkan dengan kehidupan sehari- } \\
\text { hari }\end{array}$ & Tidak & 0 & $0 \%$ \\
\hline \multirow{2}{*}{4} & Merasa senang belajar secara berkelompok dan & Ya & 24 & $100 \%$ \\
\hline & berdiskusi dengan temanmu & Tidak & 0 & $0 \%$ \\
\hline \multirow[b]{2}{*}{5} & Merasa mendapatkan suatu yang baru, & Ya & 24 & $100 \%$ \\
\hline & $\begin{array}{l}\text { sehubungan dengan materi pelajaran yang } \\
\text { disampaikan oleh guru }\end{array}$ & Tidak & 0 & $0 \%$ \\
\hline \multirow[b]{2}{*}{6} & Merasa senang mempersentasi kan hasil diskusi & $\mathrm{Ya}$ & 21 & $87,50 \%$ \\
\hline & $\begin{array}{l}\text { kelompokmu yang sudah kamu diskusikan } \\
\text { bersama ke depan kelas }\end{array}$ & Tidak & 3 & $12,50 \%$ \\
\hline \multirow[b]{2}{*}{7} & Merasa lebih mudah menerima dan memahami & Ya & 24 & $100 \%$ \\
\hline & $\begin{array}{l}\text { materi pelajaran dengan menggunakan media } \\
\text { pembelajaran Puzzle Edukasi }\end{array}$ & Tidak & 0 & $0 \%$ \\
\hline \multirow{5}{*}{8} & $\begin{array}{l}\text { Merasa lebih mudah mengerjakan soal-soal tes, } \\
\text { setelah mengikuti kegiatan pembelajaran dengan }\end{array}$ & $\mathrm{Ya}$ & 21 & $87,50 \%$ \\
\hline & $\begin{array}{l}\text { menggunakan media pembelajaran Puzzle } \\
\text { Edukasi }\end{array}$ & Tidak & 3 & $12,50 \%$ \\
\hline & & Ya & 186 & $96,88 \%$ \\
\hline & Jumian & Tidak & 6 & $3,12 \%$ \\
\hline & Kesimpulan & \multicolumn{3}{|c|}{ Respon Positif } \\
\hline
\end{tabular}

Dari hasil respon atau tanggapan siswa pada tabel 6 diketahui bahwa 96,88\% siswa merasa tertarik dan senang belajar menggunakan media pembelajaran Puzzle Edukasi. Oleh karena itu pada umumnya siswa merasa senang dan lebih termotivasi dalam mengikuti proses belajar mengajar yang disajikan oleh guru. Setelah mengikuti kegiatan pembelajaran dengan menggunakan media pembelajaran Puzzle Edukasi, semua siswa merasa lebih mudah mempelajari materi pelajaran sehingga mereka merasa lebih mudah dalam mengerjakan soal-soal tes yang disajikan baik di siklus I maupun siklus II.

Berdasarkan banyaknya jawaban ya dari siswa, maka penelitian ini dapat dikatakan berhasil karena jumlah jawaban ya adalah 96,88\% dapat memenuhi bahkan melebihi batas minimal yang telah ditetapkan pada indikator keberhasilan penelitian ini, yakni sebesar $80 \%$. Dengan demikian dapat dikatakan bahwa respon siswa terhadap pelaksanaan 
kegiatan pembelajaran dengan menggunakan media pembelajaran Puzzle Edukasi adalah positif.

\section{Penutup}

Media pembelajaran Puzzle Edukasi dapat meningkatkan aktivitas belajar siswa di kelas VIIA SMPN 6 Tanjung pada materi Norma dan Keadilan dengan skor rata-rata aktivitas siswa yang relevan dengan pembelajaran mengalami peningkatan dari siklus pertama sampai siklus kedua. Pada siklus pertama skor rata-rata aktivitas siswa meningkat dari 64,71\% menjadi 73,11\% mengalami peningkatan sebesar $8,40 \%$.

Media pembelajaran Puzzle Edukasi dapat meningkatkan aktivitas mengajar guru di kelas VIIA SMPN 6 Tanjung pada materi Norma dan Keadilan dengan skor rata-rata aktivitas guru yang relevan dengan pembelajaran mengalami peningkatan dari siklus pertama sampai siklus kedua. Pada siklus pertama skor rata-rata aktivitas siswa meningkat dari $68,42 \%$ menjadi $81,58 \%$ pada siklus kedua mengalami peningkatan sebesar $13,16 \%$.

Media pembelajaran Puzzle Edukasi dapat meningkatkan hasil belajar siswa di kelas VIIA SMPN 6 Tanjung pada materi Norma dan Keadilan dengan ketuntasan belajar pada siklus pertama 66,66\% dan pada siklus kedua menjadi $83,33 \%$ mengalami peningkatan sebesar $16,67 \%$.(nilai pengetahuan) dan ketuntasan belajar pada siklus pertama $75,00 \%$ menjadi $83,33 \%$ pada siklus kedua untuk nilai ketrampilan.(mengalami peningkatan 8,33\%).

Respon siswa secara garis besar positif terhadap proses pembelajaran menggunakan media pembelajaran Puzzle Edukasidengan persentase $96,88 \%$.

\section{Ucapan Terima Kasih}

Naskah Penelitian Tindakan Kelas ini tidak akan selesai dengan baik tanpa bantuan dari semua pihak, baik berupa motivasi, saran, 
maupun tenaganya karena itu kepada semua pihak disampaikan terima kasih sebesar-besarnya.

\section{Daftar Referensi}

Casey, E., Kudeva, R., \& Rousson, A. (2018). Institutionalization of Religion in Schools to Intercultural Education. Jurnal Ilmiah Peuradeun, 6(1), 85-102. doi:10.26811/peuradeun.v6i1.215

Kemendikbud. (2016). Buku Guru PPKn SMP/MTs Kelas VII Pusat Kurikulum dan Perbukuan, Balitbang. Jakarta: Kementrian Pendidikan dan Kebudayaan RI

Kemendikbud. (2016). Konsep dan Pedoman Penguatan Pendidikan Karakter Tingkat Sekolah Dasar dan Sekolah Menengah Pertama. Jakarta: Kementerian Pendidikan dan Kebudayaan Republik Indonesia

Saudah. (2013). Meningkatkan Aktivitas dan Hasil Belajar Siswa Pada Materi Barisan dan Deret Dengan menggunakan Model PBI SMPN 3 Paringin. Balangan

Sudijono. (2011). Pengantar Statistik Pendidikan. Jakarta: PT Raja Grafindo Persada

Widjonarko. (2011). Pengaruh Pembelajaran Matematika Dengan Study Pattern Of Students Creatifity Pada Materi Kesebangunan Siswa Kelas X. Program Studi Pendidikan Matematika FPMIPA IKIP PGRI Semarang. Semarang

Yunus, A. (2015). Pembelajaran Multiliterasi Sebuah Jawaban Atas Tantangan Pendidikan Abad Ke-21 Dalam Konteks KeIndonesiaan. Bandung: Revika Aditama 